\title{
MEASURING PUBLIC EXPENSES WITH WORKFORCE IN FIGHTING FOREST FIRE
}

\author{
Elaine Cristina Gomes da Silva ${ }^{1}$, Nilton Cesar Fiedler ${ }^{2}$, Fábio Silva Ferreira ${ }^{3}$, Lucas José Teodoro Lobato ${ }^{4}$, \\ Gabriel Mancini Antunes da Silva ${ }^{5}$, Felipe Patrício das Neves ${ }^{6}$
}

\footnotetext{
${ }^{1}$ Federal University of Espírito Santo, Department of Zootechnics, Graduate Program in Forest Sciences, Jerônimo Monteiro, Espírito Santo, Brasil - e-mail: ecristinags@gmail.com

${ }^{2}$ Federal University of Espírito Santo, Graduate Program in Forest Sciences, Jerônimo Monteiro, Espírito Santo, Brasil e-mail: nilton.fiedler@ufes.br

${ }^{3}$ Military Fire Department of Espírito Santo, Vitória, Espírito Santo, Brasil - e-mail: fabio.ferreira@bombeiros.es.gov.br

${ }^{4}$ Federal University of Espírito Santo, Graduation in Forest Engineering, Jerônimo Monteiro, Espírito Santo, Brasil e-mail: lucaslobato17@hotmail.com

${ }^{5}$ State University of Santa Catarina, Master in Forest Engineering, Lages, Santa Catarina, Brasil - e-mail: gabriel.manc99@ gmail.com

${ }^{6}$ Military Fire Department of Espírito Santo, Vitória, Espírito Santo, Brasil - e-mail: felipe.patricio@bombeiros.es.gov.br
}

Received for publication: 23/05/2019 - Accepted for publication: 10/03/2020

\begin{abstract}
Resumo
Mensuração de gastos públicos com mão de obra em combate a incêndios florestais. A frequência dos incêndios florestais e a falta de investimento nas instituições públicas advindos da atual crise econômica brasileira, emergem a dificuldade das instituições competentes em gerenciar recursos mediante ao número crescente de incêndios, principalmente a mão de obra. O objetivo deste trabalho foi mensurar os gastos com mão de obra no combate a incêndios florestais em Unidades de Conservação públicas comparando-a com a mão de obra com prevenção. Este estudo, exploratório, documental e ex post facto, foi elaborado com base em documentos e relatórios das instituições públicas envolvidas no combate a um grande incêndio ocorrido numa Reserva Biológica no Estado do Espírito Santo. Os dados foram analisados em função das instituições participantes, quantidade de participantes, cargos, valor das remunerações e dias trabalhados. Para mensurar a média diária do gasto com as diferentes remunerações, elaborou-se um modelo contábil, utilizando os valores das remunerações do ano de ocorrência do incêndio. Ao final, pôde-se concluir que, para cada 124,3 hectares queimados, trabalharam, por dia, 110 indivíduos, a maioria eram militares em início de carreira e que, o gasto com a mão de obra pública empregada no combate, tanto em quantidade quanto em remuneração, foi muito superior do que a mão de obra com a contratação temporária de brigadistas.

Palavras-chave: Proteção florestal; Prevenção de incêndios; Combate; Fogo; Gastos públicos.
\end{abstract}

\begin{abstract}
The frequency of forest fires and the lack of investment in public institutions arising from the current Brazilian economic crisis, emerges the difficulty of competent institutions in managing resources due to the increasing number of fires, mainly the labor. The objective of this work was to measure the expenses with labor in the combats against forest fires in Public Conservation Units by comparing it with the labor with prevention. This exploratory, documentary and ex post facto study was prepared based on documents and reports from public institutions involved in fighting a major fire in a Biological Reserve in the State of Espírito Santo. The data were analyzed according to the participating institutions, number of participants, positions, value of remunerations and days worked. To measure the average daily expenditure on different remunerations, an accounting model was developed, using the values of the remunerations for the year in which the fire occurred. In the end, it could be concluded that, for every 124.3 hectares burned, 110 individuals worked per day, the majority were military personnel at the beginning of their careers and that the expenditure on public labor employed in combat, both in quantity and remuneration, was much higher than the labor with the temporary hiring of firefighters.
\end{abstract}

Keywords: Combat; Fire; Fire prevention; Forest protection; Public spending.

\section{INTRODUCTION}

Currently, the discussions about the problems that involve the environment have crossed interdisciplinary contexts in order to build tools that assist in decision taking that also involve social and economic aspects. In this context, forest fires stand out as one of the main problems faced by forest managers, due to the limited amount of equipment and financial and human resources, as well (TORRES et al., 2016).

According to Rodriguez et al. (2014), forest fires are characterized by high levels of destruction of natural and human capital, imposing large financial, environmental and human burdens on the society.

According to Eugenio et al. (2016), the discussion on the theme of fire among public and private institutions and the civil society is of paramount importance for the progress of prevention activities. According

FLORESTA, Curitiba, PR, v. 50, n. 4, p. 1912 - 1920, out/dez 2020.

Silva, E. C. G. et.al.

ISSN eletrônico 1982-4688

DOI: $10.5380 /$ rf.v50 i4. 67022 
to Canzian et al. (2016), this is one of the major causes of damage in the forest environment, i.e., it provides economic, social and environmental damages.

Even though fire is part of the natural process of the management in several types of ecosystems, in which many animals and plants need it to survive, there are ecosystems that are very sensitive to fire (Silva et al., 2018). The climatic changes of the last decades and the long periods of drought results in a tendency of increasing the frequency and intensity of the occurrences of fire caused by high temperatures (KELLY; BROTONS, 2017). For Oliveira Júnior et al. (2017), the number of outbreaks of forest fires and burnings has increased significantly in the country. In addition, in the last 20 years, there has been a considerable raise in the interest in forest fire events, especially with regard to the Environmental Preservation Areas.

In Brazil, the Conservation Units were created with the objective of protecting the biota; however, some are affected with fire events in its interior and surroundings every year. According to the Chico Mendes Institute for Biodiversity Conservation (ICMBIO), most problems in the Conservation Units are directly linked to the scarcity of financial resources (ICMBIO, 2012).

Thus, public management imposes a challenge to be overcome, which is the maximization of the use of public resources made available, because, whether improperly used, they can cause effects contrary to their objectives (GRACILIANO; FIALHO, 2013). It should be underlined that, according to Neduziak and Correia (2017), Brazil is going through an economic crisis that started in 2014 and, for this reason, there are budget restrictions in the public budget that affect all areas, including the environment. Thus, in view of the forecasts of growth in the number of forest fires (MASCARANHAS; BROWN; SILVA, 2018), it is believed that the demand for skilled labor in fighting forest fires will increase significantly, thus requiring more resources from public institutions as it is also believed that the public expenditures used with the combat are higher than the expenditures used for preventing fires in areas of environmental preservation.

According to Torres et al. (2017), historical data and a good forecast index facilitate adequate policies for the quantification and distribution of prevention resources, aiming at reducing losses and, consequently, financial and environmental losses. Tebaldi et al. (2012) claim that in the State of Espírito Santo, a significant portion of the occurrences of forest fires in Conservation Units and other protected areas is associated with the lack of strategic management policies related to prevention. For Rezende et al. (2010), the promotion of efficiency in the public sector depends on the authorities having reliable information on the expenses incurred by different agencies in the provision of services maintained by public institutions.

That said, the importance of studies on expenses with fighting forest fires is highlighted, which is difficult to be measured due to the lack of reliable tools and records that provide such measurement. Thus, based on the above, the objective of this work was to measure the labor employed to fight a large forest fire in the Sooretama Biological Reserve, in the State of Espírito Santo, by comparing the public sector labor employed in the combat with that used in the prevention.

\section{MATERIAL AND METHODS}

This study is classified as documentary, descriptive and Exploratory. It approaches the quantitative and qualitative aspects of a case study, ex post facto, in whihc it was raised the information about the labor employed in combating a major forest fire that occurred in the Sooretama Biological Reserve (RBS) in northern State of Espírito Santo, in March 2016.

\section{Sooretama biological Reserve}

The Reserve, created in 1982, is an Integral Protection Unit belonging to the Federal Government, managed by the Chico Mendes Institute for Biodiversity Conservation (ICMBIO). It is the largest area of native forest cover in the State, with approximately 24,000 hectares. Its predominant vegetation formation is of Dense Ombrophylous Forest in the lowlands, characterized by trees over 30 meters high and with great diversity of ecosystems, while the topography covers a flat strip of about 20 to 200 meters above sea level. The fauna community is typical of Atlantic Rain Forest, whihc is similar the Amazon fauna and with a large number of endemic species, which is why the Reserve was created (INSTITUTE OF THE ENVIRONMENT AND RENEWABLE NATURAL RESOURCES - IBAMA, 2009).

According to Paula and Soares (2011), the soils are mostly classified as Dystrophic Red-Yellow Latosols and the climate in the region is classified as humid tropical, with an average annual rainfall of 1,403 $\mathrm{mm}$ and a dry season from May to September. The average annual temperature is $23.6^{\circ} \mathrm{C}$, with a minimum temperature of 15.6 ${ }^{\circ} \mathrm{C}$ in July.

In March 2016, RBS recorded its second largest fire, where approximately 1,610.87 hectares were burned. Figure 1 illustrates the location of the RBS with the burned áreas.

FLORESTA, Curitiba, PR, v. 50, n. 4, p. 1912 - 1920, out/dez 2020.

Silva, E. C. G. et.al.

ISSN eletrônico 1982-4688

DOI: $10.5380 /$ rf.v50 i4. 67022 


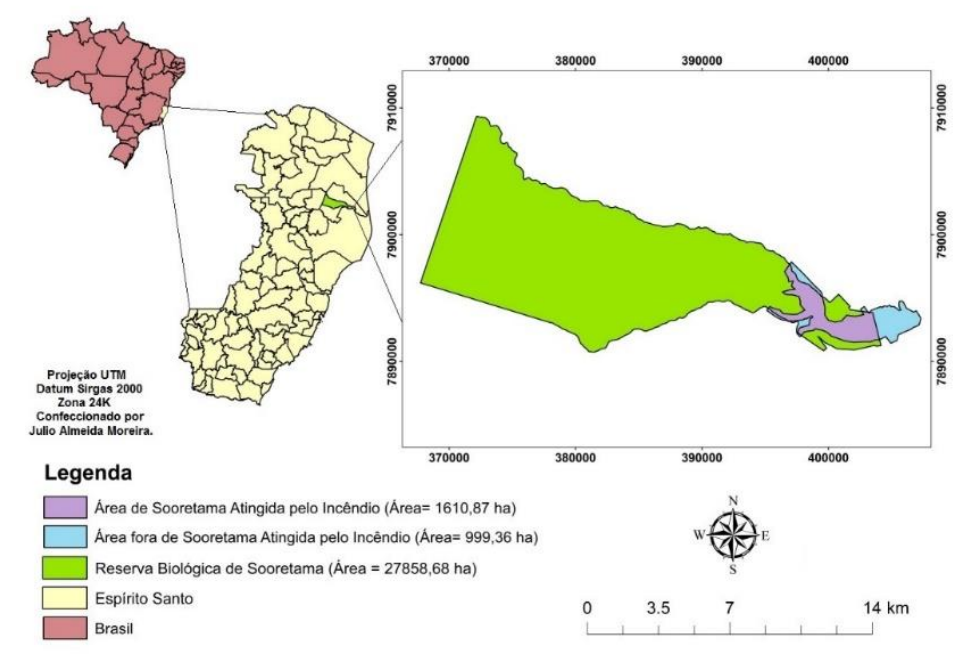

Figure 1. REBIO Sooretama and areas affected by the fire.

Figura1. Reserva Biológica de Sooretama e áreas atingidas pelo incêndio.

Source: Silva (2017).

Data source, collection and elaboration

The information in this study is restricted to documents issued by public institutions of the Federal, State and Municipal autarchies, regarding to the variables amount, type and values of the remuneration of the labor identified in the fire-fighting jobs, whihc were tabulated per day of combat, per institution and per type of labor employed, in order to know the quantity of labor employed in the combat, per hectare burned, as well as the value of the remunerations of the individuals who worked, in order to know the financial profile invested in the labor employed in fighting forest fires in an area under the responsibility of the State.

The following steps were performed for data collection:

a) Investigation of public institutions that contributed with labor in fighting the fire;

b) Execution of semi-structured in loco interviews, at the General Command and Military Firefighter Battalions in the cities of Linhares and São Mateus, all in the State of Espírito Santo;

c) Requests by means of letters of information on the labor used by each institution;

d) Analysis of the Reports on the Operation in Sooretama Biological Reserve of the do 2nd Military Firefight Battalion in Linhares-ES;

e) Analysis and Tabulation of the information received through Electronic System of Citizen Information Servicee-SIC; and General Administration of the State of Espírito Santo.

The Official Data for this study were provided by 17 public institutions, highlighted as follows:

a) Brazilian Army (38 ${ }^{\text {th }}$ Infantry Battalion of Espírito Santo State);

b) Operation and Air Transport Center of ES - NOTAer;

c) Military House of the Government of the Espirito Santo State - CM;

d) General Command of the Military Firefighter of the State of Espírito Santo - CBMES

e) Brazilian Institute for the Environment and Renewable Natural Resources- IBAMA;

f) Chico Mendes Institute for Biodiversity Conservation- ICMBIO;

g) Environment Ministry;

h) São Mateus City Hall;

i) Conceição da Barra City Hall;

j) Linhares City Hall;

k) Sooretama City Hall;

1) State Institute for the Environment and Water Resources - IEMA - ES;

m) Goytacazes National Forest - FLONA Goytacazes/ICMBIO-ES;

n) Serra dos Órgãos National Park - PARNASO/ICMBIO/Rio de Janeiro-RJ;

o) Comboios Biological Reserve - REBIO COMBOIOS/ICMBIO-ES;

p) Electronic System of the Citizens Information System (e-SIC);

q) General Administration of the State of Espírito Santo.

FLORESTA, Curitiba, PR, v. 50, n. 4, p. 1912 - 1920, out/dez 2020. 
On the remuneration

To measure the values spent on the remuneration of all the labor, the total gross amounts received by the individuals identified in the documents of the public institutions that worked in the combat were considered. For that, the simple arithmetic mean was used. The determinations of the Federal General Comptroller (CGU, 2017) were also taken as guidelines:

a) Basic pay: composed of the sum of the remuneration installments corresponding to the position, function or commissioned position; and made up by the sum of the wage installments corresponding to the position, function or commissioned position; and

b) Sporadic pay: Christmas bonus ( $13^{\text {th }}$ salary); vacation (one-third of the salary).

To obtain the total gross remuneration values of the military personnel belonging to the State authority (Military Fireman; Military Personnel of the Operations and Air Transport Center of Espírito Santo - NOTAer), the Table of Subsidies and Wages of the active military personnel in force in the year of the fire ( Law No. 10,185 of 2013, of the State of Espírito Santo) was used. It was not possible to identify the value of the individual remuneration of each military officer because in the daily reports of the combat operation that were analyzed, all military personnel were identified by career and surname. It should be stressed that the values of the military's remuneration for the year of the fire in question (2016) were considered.

Thus, an average remuneration value was obtained for each type of military career (Graduation and Rank), considering the hierarchy and horizontal reference of each career level (Tables 1 and 2) and the simple arithmetic mean was used to obtain the total remuneration for each type of career, as the military had different careers and worked in more than one day in the combat.

Table 1. Values of the wage means of the Military Firefighters.

Tabela 1. Valores das médias de remuneração dos Bombeiros Militares.

\begin{tabular}{lcc}
\hline $\begin{array}{c}\text { Career } \\
\text { Graduation / } \\
\text { Rank }\end{array}$ & $\begin{array}{c}\text { Wage average } \\
\text { value } \\
\text { +gross GSE } \\
(\mathbf{R} \mathbf{\text { ) }}\end{array}$ & $\begin{array}{c}\text { Total expenditure } \\
\text { Per category }(\mathbf{R} \mathbf{)})\end{array}$ \\
\hline Private & $3,518.70$ & $31,290.35$ \\
Corporal & $4,424.74$ & $13,438.10$ \\
Sargent & $6,110.36$ & $14,483.81$ \\
Sub-lieutenant & $7,163.85$ & $1,326.64$ \\
Lieutenant & $8,954.81$ & $16,582.99$ \\
Capitan & $10,794.51$ & $4,397.76$ \\
Major & $13,277.24$ & $6,392.74$ \\
Lieutenant/Colonel & $15,932.68$ & $1,770.30$ \\
\hline Source: Research data. & &
\end{tabular}

Table 2. Values of the means of the wages of the NOTAer military personnel.

Tabela 2. Valores das médias de remuneração dos Militares do NOTAer.

\begin{tabular}{lcc}
\hline $\begin{array}{c}\text { Career } \\
\text { Graduation/ } \\
\text { Rank }\end{array}$ & $\begin{array}{c}\text { Mean value } \\
\text { Gross GSE } \\
(\mathbf{R} \$)\end{array}$ & $\begin{array}{c}\text { Total expenditure } \\
\text { Wage per } \\
\text { category }(\mathbf{R} \$ \mathbf{)}\end{array}$ \\
\hline Private & $3,518.70$ & $2,215.48$ \\
Corporal & $4,424.74$ & 819.40 \\
Capitan & $10,794.51$ & $7,596.14$ \\
Major & $13,277.24$ & 491.75 \\
\hline Source: Research & &
\end{tabular}

Source: Research data.

For the values of the Brazilian Army, Federal autarchy, the gross values (wage and military bonus) provided by the Brazilian Army for the year 2016 (TABLE 3) were used, obtaining the average values of the remunerations for each type of military career of the same way as Tables 1 and 2.

FLORESTA, Curitiba, PR, v. 50, n. 4, p. 1912 - 1920, out/dez 2020. 
Table 3. Values of the wage averages of the Military of the Brazilian Army.

Tabela 3. Valores das médias de remuneração dos Militares do Exército Brasileiro.

\begin{tabular}{lcc}
\hline $\begin{array}{c}\text { Career } \\
\text { Graduation/ } \\
\text { Rank }\end{array}$ & $\begin{array}{c}\text { Average value } \\
\text { Gross GSE (R\$) }\end{array}$ & $\begin{array}{c}\text { Total expenditure } \\
\text { Wage per } \\
\text { category } \\
\mathbf{( R \$ )}\end{array}$ \\
\hline Private & $1,747.50$ & $4,547.73$ \\
$3^{\text {rd }}$ Sargent & $2,803.75$ & $5,297.44$ \\
$2^{\text {nd }}$ Sargent & $4,522.00$ & $7,122.81$ \\
Lieutenant & $5,562.20$ & $4,972.61$ \\
Aspirant/Officer & $7,854.36$ & $3,199.92$ \\
$2^{\text {nd }}$ Lieutenant & $7,458.92$ & $1,236.04$ \\
1st Lieutenant & $8,741.63$ & $14,570.89$ \\
Capitan & $10,216.50$ & $16,510.97$ \\
Source: Research data. & $11,162.62$ & $47,635.56$ \\
\hline
\end{tabular}

For a better understanding of the results, the remunerations were classified in categories according to Table 4.

Table 4. Labor categories.

Tabela 4. Categorias da mão de obra.

\begin{tabular}{lcl}
\hline \multicolumn{1}{c}{ Category } & & \multicolumn{1}{c}{ Wage Composition } \\
\hline Brazilian Army & EB & Wage +Military bonus \\
Military Firefighter & BM & Allowance + GSE \\
NOTAer Military & MN & Allowance + GSE \\
Other civil workers & DSP & Gross remuneration \\
\hline
\end{tabular}

* Monthly installment inherent to each hierarchical circle of the military career; **Extraordinary service bonus. Source: prepared by the authors.

To obtain the values of the remunerations of the three categories of military personnel, Equations 1 to 4 were prepared.

In relation to the remuneration values of the other public servers, the gross values were obtained individually through e-SIC, after the identification of all individuals who worked in the combat, these values being obtained through Equation 5.

$$
\begin{gathered}
\left.R E B=\sum\left(S A D_{b m} / T_{2} \times Q M\right)+\left(D_{3} / T_{1} / T_{2} \times Q M\right)+\left(\frac{S A D_{b m}}{3} / T_{1} / T_{2} \times Q M\right)\right)(1) \\
\left.R B M=\sum\left(S_{b m} / T_{2} \times Q M\right)+\left(D_{3} / T_{1} / T_{2} \times Q M\right)+\left(\frac{S_{b m}}{3} / T_{1} / T_{2} \times Q M\right)\right)(2) \\
\left.R M N=\sum\left(S_{b m} / T_{2} \times Q M\right)+\left(D_{3} / T_{1} / T_{2} \times Q M\right)+\left(\frac{S_{b m}}{3} / T_{1} / T_{2} \times Q M\right)\right)(3) \\
T R M=T_{s o} E B+T_{s u} B M+T_{s u} M N(4) \\
\left.R D S=\sum\left(R_{b m} / T_{2} \times D T\right)+\left(D_{3} / T_{1} / T_{2} \times D T\right)+\left(\frac{R_{b m}}{3} / T_{1} / T_{2} \times D T\right)\right)(5)
\end{gathered}
$$

where: $\mathrm{REB}=$ Brazilian Army Pay, $\mathrm{SAD}_{\mathrm{bm}}=$ monthly gross military wage and bonus, $\mathrm{T}_{2}=30$ days, $\mathrm{QM}=$ number of military personnel in career $\mathrm{X}, 3=$ proportion of the thirteenth salary; $\mathrm{T}_{1}=12$ months; $\mathrm{RBM}=$ gross monthly remuneration, $\mathrm{S}_{\mathrm{bm}}=$ gross monthly allowance, $\mathrm{RMN}=$ NOTAer military remuneration; $\mathrm{TRM}=$ total military remuneration; $\mathrm{T}_{\mathrm{so}} \mathrm{EB}=$ total wages of all levels of the Brazilian Army; $\mathrm{TsuBM}=$ total subsidies for military firefighters; $\mathrm{T}_{\mathrm{su}} \mathrm{MN}=$ total subsidies for NOTAer military personnel and RDS = remuneration for other servers.

To obtain the average amount spent on wages of labor employed per hectare burned, the result of the sum of Equations 4 and 5 was divided by the total number of hectares burned in the Reserve. It should be observed that the values shown in this study are those calculated in the period of the fire and do not have any type of monetary adjustment. The results are presented using descriptive statistics. 


\section{RESULTS}

The estimate of total public financial expenditure in payments for the employment of seven different labor groups, which totaled 256 professionals identified in the 21 days of firefighting was, at least, $\mathrm{R} \$ 289,720.17$. The average total daily expenditure for the remuneration of military labor (70\%) was $\mathrm{R} \$ 20,200.00$, while for other civil servants, it was $\mathrm{R} \$ 6,625.00$ (20\% of labor). The qualification of unidentified labor (many volunteers) and private companies totaled $10 \%$ of the total volume. The labor employed in the aftermath period was not counted, as there were not enough records with information about the individuals who worked (the vast majority of firefighters).

It was also observed that the same individuals worked to fight the fire in different amounts and on different days. Thus, the results discussed in this work are mostly shown by daily averages, obtained through Equations 1 to 5 .

For each 124.30 hectares burned daily, inside and on the borders of the CUs, an average of 110 individuals was found working, accounting for the total value of their remuneration at $\mathrm{R} \$ 26,825.00$.

Brazilian Army labor (EB)

The Brazilian Army (federal autarchy), specifically the $38^{\text {th }}$ Infantry Battalion of the State of Espírito Santo, represented $60 \%$ of the total amount of military labor employed in the combat. In 11 days of work in this military category, this contingent made an average daily expense of $\mathrm{R} \$ 11,100.00$ with remuneration (17\% more than the average of the Firefighters). Thirty-nine army soldiers worked a day, out of which, 94\% were at the beginning of their career (Graduation). It is noteworthy that the expenses incurred with the transfer and support of these military personnel, such as: maintenance and fuel of military vehicles (16 heavy vehicles and approximately 6,500 liters of Diesel), equipment for the military's camp, those were expenses related to the $38^{\text {th }}$ Battalion infantry).

\section{Military Firefighter labor (BM)}

Regarding the Military Firefighters (state authority) labor, 24 firefighters from different municipalities in the State of Espírito Santo worked all the 21 days of combat. Of these, $83 \%$ were in the undergraduate career, accounting, on a daily average, the amount of $\mathrm{R} \$ 7,000.00$ with remuneration. However, for the transfer of these soldiers, there was expenses with 26 light vehicles, their maintenance and about 2667 liters of gasoline.

\section{NOTAer Military Labor (BN)}

Regarding the NOTaer Military, the workforce was two soldiers per day and, for this military category, the average between both careers (Graduate or Officer) was the same, as according to NOTAer itself, only Officers can pilot the aircraft (three aircrafts were used in this combat). Thus, the daily average remuneration of these military personnel was $\mathrm{R} \$ 2,100.00$ considering 10 days worked. It should be highlighted that the aircrafts made the route between REBIO Sooretama and the Municipality of Vitória daily, to supply them and change the pilots.

Labor of other workers (DS)

This labor is regarded to 16 servers from three ICMBIO Conservation Units (administrative assistant, environmental technician and environmental analyst), who worked for 20 days, alternately with each other involving three Municipalities (only drivers who worked only 2 days, due to the lack of experience with the topography of the burned area). The average daily expense, with the remuneration of these employees was $\mathrm{R} \$$ $6,825.00$, of which only $\mathrm{R} \$ 540.00$ came from the remuneration of three drivers.

\section{DISCUSSION}

\section{Military labor}

Considering all military categories, on a daily average, 65 soldiers worked day and night, of which the great majority stopped working in the activities inherent to the military function to which they belong, to work in the firefighting at REBIO in Sooretama, such as, for example , NOTAer Military personnel, whose main responsibility is to plan, coordinate, control and execute police, aeromedical and civil defense operations.

It should be clarified that, due to the scale of the fire that occurred at REBIO in Sooretama and due to the lack of hired labor from brigade members at REBIO (there were no hired firefighter) and from military firefighters to work in the firefighting (several fires occurred in parallel to the REBIO), the Brazilian Army was asked for help with labor. According to one of the investigated documents, the Firefighters evaluated the fire "as of high complexity and high risk, even for the most experienced Firefighters" (ESPÍRITO SANTO, 2016, p. 70). However, it was also found that the Army Military, the vast majority at the beginning of their careers, did not perform night monitoring and always needed to be accompanied by Firefighters, as they had no experience in fighting forest fires and were working on a major event. Combat and nighttime monitoring were hampered by the lack of skilled labor.

FLORESTA, Curitiba, PR, v. 50, n. 4, p. 1912 - 1920, out/dez 2020. 
The State of Espírito Santo, represented by the labor of the Notaer Military and Military Firefighters, ranked in place with the use of labor in the combat, although REBIO de Sooretama is under the control of the Federal autarchy. Firefighters' labor was not greater due to the number of employees. Hence, according to the Personnel Management Board of the Fire Department of the State of Espírito Santo, in the year when the fire occurred, there were 1,185 active military firefighters throughout the State of Espírito Santo, of which only 34 have specific training in forest fires and in 2019 there were 1,121 firefighters on duty. Since 2009, there have been two specific courses in Specialization in Prevention and Fighting Forest Fires (CPECIF). However, according to information from that sector, there is no periodicity for this type of training, which has not occurred since 2013. According to Machado Neto (2017), it is necessary to expand the fire prevention system in the months preceding the critical period and the training of the firefighting brigade.

Thus, it is believed that, with a greater number of firefighters with specific and periodic training in forest fires (in addition to the basic training they already have), the chances of more effective suppression of large-scale forest fires increase. Consequently, this contributes to the economy of other resources besides the labor, because, even if there are trained firefighters in the Conservation Units, who are usually temporarily hired, when the fires start to have great proportions, like in this study, most of the labor comes from military firefighters, who also perform many other functions besides fighting forest fires.

\section{Labor of other workers}

For the purpose of comparing the costs of prevention and combat, the value of the monthly remuneration of a firefighter ( $\mathrm{R} \$ 1,338.00)$ and the Chief of Brigade ( $\mathrm{R} \$ 1,659.00)$, temporarily hired by ICMBIO in the same year of the fire, was investigated. The composition of this remuneration was thus informed through the e-SIC "the firefighter's salary is formed by 1 (one) minimum wage, plus food, transportation and pre-school assistance."

It was also observed that, although ICMBIO had hired 16 brigade members to work in the Sooretama Reserve for 6 months (maximum period for hiring brigade members) with a total expense of the Federal autarchy of $\mathrm{R} \$ 134,160.76$. The hiring-period of these firefighters was in the months of July to December 2016. However, in the month of the fire, March, there was no firefighter hired because the contract of the previous year was expired and another contract had not been carried out or renewed. It should be underlined that, two months before the fire occurred, in December 2015, REBIO of Sooretama had already suffered a forest fire.

When asked about the criteria used to hire firefighters, ICMBIO reported: "what determines the number of firefighters to be hired in each Conservation Unit are the history of fires, deforestation and climatic factors, inherent to each of them".

Finally, although it was not possible to account for lack of adequate records, it was observed that other professionals worked voluntarily in fighting the fire, such as: veterinarians, biologists, forestry and environmental engineers.

Meals and drinking water for all who worked in the combat were mostly provided by private companies that also provided support from their employees to help fight the fire, whether with large vehicles or operational equipment, as those whihc were available was insufficient and there was a lack of skilled labor.

All the labor officially employed, were civil servants of the Municipal, State and Federal autarchies. Therefore, they did not receive overtime, nighttime or unhealthy work bonus (in Brazil, military personnel do not receive these benefits, even the firefighters).

\section{CONCLUSIONS}

- This study allowed to observe the amount of labor employed, per hectare burned, in a large forest fire in an area of environmental preservation under the responsibility of the State.

- The employment of at least 170 military personnel and the expenses resulting from their locomotion in war vehicles, could have been avoided, as well as the environmental impacts that occurred in the burned area in the Reserve.

- For every 124.30 hectares burned per day, in the interior and limits of the REBIO of Sooretama, the number of approximately 110 individuals working in combat was determined, the vast majority of the Brazilian Army, specifically the Infantry Battalion, with the average daily expense of $R \$ 26,825.00$ in payments with the military and other civil servants.

- The vast majority of firefighters had no experience in fighting forest fires and were at the beginning of their careers. They helped due to the lack of labor due to the size of the fire, because at that time there were no firefighters hired at REBIO in Sooretama.

- Comparatively, the measurement of the amount spent per day on public sector labor employed in the combat would be enough to hire, on average, 17 firefighters per month. 
- The total measurement of the labor employed in this combat was, at least, $\mathrm{R} \$ 289,720.00$ for the 21 days of firefighting. The contract value of 16 firefighters for 6 months cost the Federal government R\$ $134,160.76$ at the time of the fire.

- The measured financial values of the wages, both for the military and other civil servants, corroborate the urgent need for the State itself to invest more in prevention, with the hiring of firefighters, aiming at the appropriate use of public resources, in addition to preserving the environment since the vast majority of the labor were military and were out of function. In addition, they did not receive overtime, nighttime or unhealthy work bonuses.

- Voluntary labor and private companies were of paramount importance in the fight, as public material, human and financial resources were insufficient. In addition, there was a lack of skilled labor to operate machinery and heavy vehicles.

- $\quad$ Finally, this work expands the field of evaluation of the competent public agencies regarding the raise in investments in preventive measures, since the expenses with combat are much higher. The primary action should be to provide mechanisms for rapid detection and immediate action in combat. Thus, it is possible that the environmental, economic and social damages could be reduced even become reversible.

\section{ACKNOWLEDGMENTS}

To the Military of the $38^{\text {th }}$ Infantry Battalion of the State of Espírito Santo, to the Military of the NOTAer and, in particular, to the Military Firefighters of the State of Espírito Santo, for their great collaboration in detailing and clarifying the information.

To those responsible for the public institutions consulted, for the preparation and provision of data that made this work possible.

\section{REFERENCES}

CANZIAN, W. P.; FIEDLER, N. C.; BRINATI, I. B.; JUVANHOL, R. S.; BIGHI, K. N. Diferentes concentrações de retardante de fogo em plantios de eucalipto. Nativa, Sinop, MT, v. 4, n. 4, p.195-198, jul./ago. 2016.

CASA MILITAR DO ESPÍRITO SANTO. NOTAer. Disponível em: < https://casamilitar.es.gov.br/notaer-2>. Acesso em 29/04/2019.

CONTROLADORIA GERAL DA UNIÃO (CGU). Consulta remuneração. Disponível em: <http://www.portaldatransparencia.gov.br/servidores/SAIBA\%20MAIS.pdf>. Acesso em: 25 set. 2017.

EUGENIO, F. C.; FIEDler, N. C.; RIBEIRO, G. A.; SIlVA, A. G.; SANTOS, A. B.; PANETO, G. G.; SCHETTINO, V. R. Applying GIS to develop a model for forest fire risk: a case study in Espírito Santo, Brazil. Journal of Environmental Management, v. 173, p. 65-71, 2016.

ESPÍRITO SANTO. $2^{\circ}$ Batalhão do Corpo de Bombeiros Militar. Linhares, ES, 2016, 116 p. (Relatório da Operação na Reserva Biológica de Sooretama 2016).

GLOBAL FIRE MONITORING CENTER (GFMC). Vegetation fires and global change. Challenges for concerted international action. A white paper directed to the United Nations and International Organizations. Germânia, 2013. Disponível em: <http://www.fire.uni-freiburg.de/latestnews/Vegetation-Fires-Global-ChangeUN-White-Paper-GFMC-2013.pdf>. Acesso em: 8 set. 2017.

GRACILIANO, E. A.; FIALHO, W. C. D. Registro da depreciação na Contabilidade Pública: uma contribuição para o disclosure de gestão. Pensar Contábil, Rio de Janeiro, v. 15, n. 56, p. 14 - 21, jan./abr. 2013.

INSTITUTO CHICO MENDES DE CONSERVAÇÃO DA BIODIVERSIDADE (ICMBIO). Efetividade da Gestão das UCs federais. Brasília: ICMBio/WWF, 2012.

INSTITUTO BRASILEIRO DE MEIO AMBIENTE E DOS RECURSOS NATURAIS RENOVÁVEIS (IBAMA). Relatório de ocorrências de incêndios em Unidades de Conservação Federais 2005-2008. Brasília, 2009.

KELLY, L. T.; BROTONS, L. Using fire to promote biodiversity. Forest ecology and management. Science, v. 355, p. 1264-1265, mar. 2017.

MASCARENHAS, F. S.; BROWN, I. F.; SILVA, S. S. Desmatamento e incêndios florestais transformando a realidade da Reserva Extrativista Chico Mendes. Desenvolvimento e Meio Ambiente, Paraná, v. 48, Edição especial: 30 Anos do Legado de Chico Mendes, p. 236-262, novembro 2018.

FLORESTA, Curitiba, PR, v. 50, n. 4, p. 1912 - 1920, out/dez 2020. 
MACHADO NETO, A. P.; BATISTA, A. C.; BIONDI, D. S.; SOARES, R. V.; BATISTA, A. P. Incêndios florestais no Parque Nacional da Chapada dos Guimarães-MT entre 2005 e 2014. Nativa, Sinop, MT, v. 5, n. 5, p. 355-361, set./out. 2017.

NEDUZIAK, L. C. R.; CORREIA, F. M. Alocação dos gastos públicos e crescimento econômico: um estudo em painel para os estados brasileiros. Administração Pública, Rio de Janeiro, vol.51, no.4, July/Aug. 2017.

OLIVEIRA JÚNIOR, J. F. Relação entre o Standardized Precipitation Index (SPI) e os Relatórios de Ocorrência de Incêndios (ROI) no Parque Nacional do Itatiaia. Floresta e Ambiente, Rio de Janeiro, v. 24, p. 1-9, 2017.

PAULA, A. de; SOARES, J. J. Estrutura horizontal de um trecho de floresta ombrófila densa das terras baixas na Reserva Biológica de Sooretama, Linhares, ES. Floresta, Curitiba, v. 41, n. 2, p. 321-334, abr./jun. 2011.

REZENDE, F.; CUNHA, A.; BEVILACQUA, R. Informações de custos e qualidade do gasto público: lições da experiência internacional. RAP, Rio de Janeiro, v. 44, n. 4, p. 959-92, jul./ago. 2010.

RODRIGUEZ, M. P. R.; SOARES, R. V.; BATISTA, A. C.; TETTO, A. C.; REINA, J. M. C.; BECERRA, L. W. Eficiencia de la protección contra incendios forestales em Monte Alegre, Brasil ypinar del río, Cuba. Floresta, Curitiba, v. 44, n. 4, p. 617-628, out./dez. 2014.

SILVA, E. C. G. FIEDLER, N. C.; JUVANHOL, R. S.; SILVA, G. M. A.; NEVES, F. P. Análise temporal da ocorrência de incêndios florestais nas Américas e região do Caribe. Nativa, Sinop, MT, v. 6, n. 5, p. 491-495, set./out. 2018.

TEBALDI, A. L. C.; FIEDLER, N. C.; JUVANHOL, R. S.; DIAS, H. M. Ações de prevenção e combate aos incêndios florestais nas Unidades de Conservação estaduais do Espírito Santo. Floresta e Ambiente, Rio de Janeiro, v. 20, n. 4, p. 538-549, out./dez. 2012.

TORRES, F. T. P.; LIMA, G. S.; MARTINS, S. L.; VALVERDE, S. R. Analysis of efficiency of fire danger indices in forest fire Prediction. Revista Árvore, Viçosa, MG, v. 41, n. 2, 2017.

TORRES, F. T. P.; LIMA, G. S.; COSTA, A. G.; ARAÚJO, G.; SILVA JÚNIOR, M. R. Perfil dos incêndios florestais em Unidades de Conservação Brasileiras no período de 2008 a 2012. Floresta, Curitiba, PR, v. 46, n. 4, p. 531-542, out. / dez. 2016.

FLORESTA, Curitiba, PR, v. 50, n. 4, p. 1912 - 1920, out/dez 2020. 